Document downloaded from:

http://hdl.handle.net/10251/84501

This paper must be cited as:

Torregrosa López, JI.; Lo-lacono-Ferreira, VG.; Martí Barranco, C.; Bellver Navarro, CG. (2016). The strengths of EMAS as an environmental management system for European university campuses. International Journal of Environment and Sustainable Development. 15(1):89-106. doi:10.1504/IJESD.2016.073339.

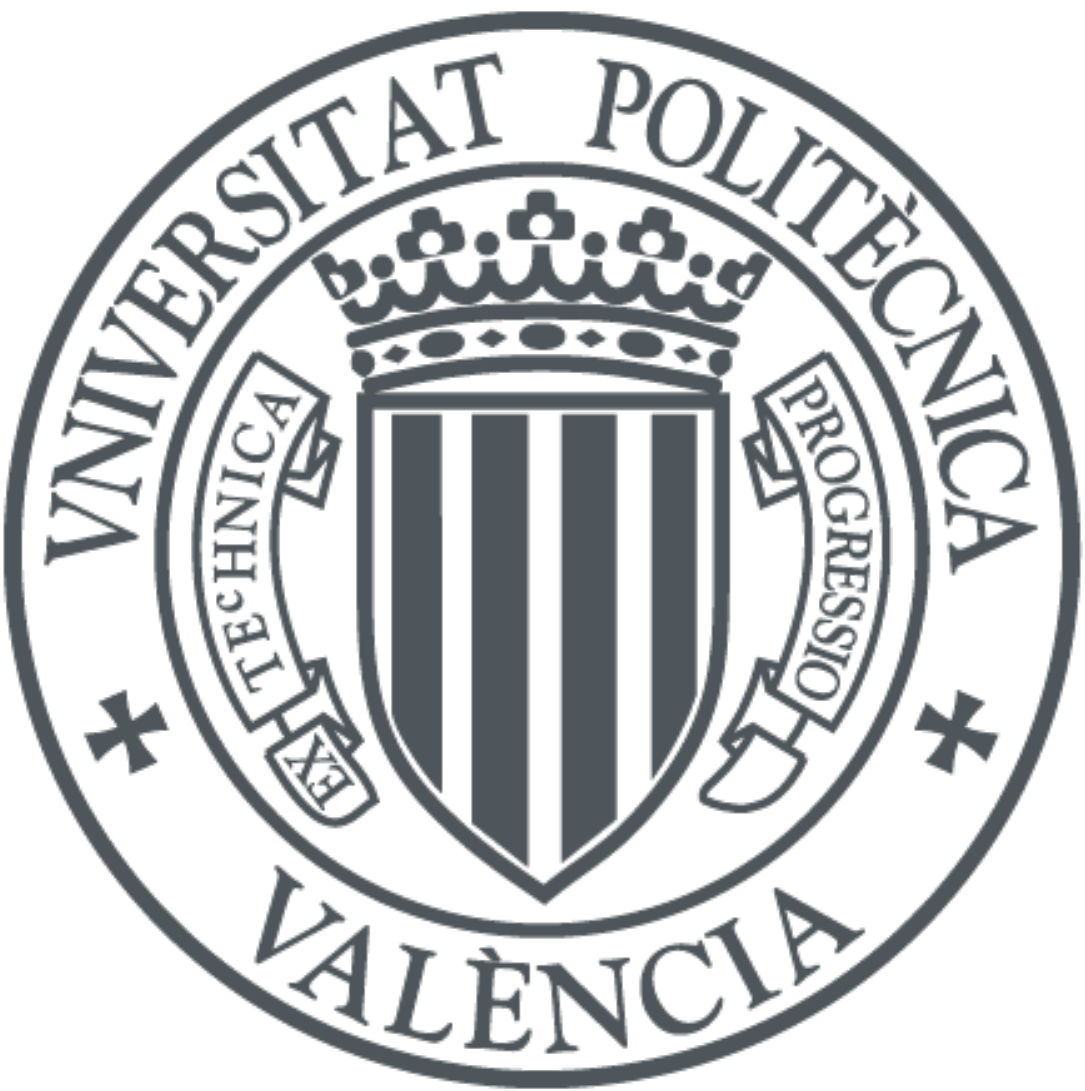

The final publication is available at

http://dx.doi.org/10.1504/IJESD.2016.073339

Copyright Inderscience

Additional Information 


\title{
THE STRENGTHS OF EMAS AS AN ENVIRONMENTAL MANAGEMENT SYSTEM FOR EUROPEAN UNIVERSITY CAMPUSES
}

\author{
Juan Torregrosa-López*, Vanesa Lo-Iacono-Ferreira, Cristina Martí- \\ Barranco, Carmen-Gemma Bellver-Navarro
}

*Universitat Politècnica de València. Pz Ferrándiz y Carbonell 1, 03801 (Alcoy) Alicante, Spain jitorreg@iqn.upv.es

\section{Dr. Juan Torregrosa-López \\ jitorreg@iqn.upv.es}

Dr. Juan Ignacio Torregrosa López gained his Degree in Chemistry at Universidad de Alicante in 1990 and PhD in Chemistry in 1995 at Universitat Politècnica de València (UPV) where he became lecturer in Chemical Engineering and it is currently Director of Teaching in Engineering Faculty of Alcoy Campus. As well he continues with his research activities in chemical engineering processing he carries out research in the area of environmental indicators for organizations in Industrial, Radiophysical and Environmental Safety Institute of UPV. Dr Juan Ignacio Torregrosa-López is the corresponding author and can be contacted at: jitorreg@iqn.upv.es

\section{Vanesa Lo-Iacono-Ferreira}

valoia@epsa.upv.es

Vanesa Lo-Iacono-Ferreira gained her degree in Chemical Engineering in 2009 and her master in Textile Engineering in 2011 at Universitat Politècnica de València (UPV) where nowdays is $\mathrm{PhD}$ student. Her research focuses on sustainability and its indicators for complex organizations. She has collaborated as researcher in several projects of Industrial, Radiophysical and Environmental Safety Institute of UPV. 


\section{Cristina Martí-Barranco}

crimarba@upvnet.upv.es

Cristina Martí-Barranco gained her degree in Agronomist Engineering in 1997 at Universitat Politècnica de València (UPV). She enrolled in Environmental Office at UPV in 1997 where she has been in charge of the coordination of carrying out the implementation, verification and maintenance of EMAS at UPV. She has published several papers and communications about the role of EMAS in university campuses.

\section{Carmen-Gemma Bellver-Navarro}

cnavbe@hotmail.com

Carmen Gemma Navarro-Bellver gained her degree in Environmental Science at Universitat Politècnica de València (UPV) in 2003. She joined the Environmental Office of Universitat Politècnica de València (UPV) that where she has formed part of the team that have carried out the implementation, verification and maintenance of EMAS at UPV. During this period she has also collaborated as researcher in severa projects of Industrial, Radiophysical and Environmental Safety Institute of UPV.

\section{ABSTRACT}

Universities are unique organizations that have a full range of existing environmental issues, particularly for those that perform research in technical fields. Implementing an environmental management system has been proposed as a way for educational organizations to track and improve the management of these environmental issues. Although only a handful of universities have been verified in the European Union Eco-Management Environmental Audit Scheme (EMAS), there have been a large number of institutions and companies all over Europe that have become registered. The complexity of universities, including research and teaching activities and governance structures, have resulted in EMAS implementation barriers that industrial sector companies do not necessarily face. 
This study analyzes the specific barriers, benefits, and challenges of the implementation process of the EMAS at Universitat Politècnica de València (UPV). As a result, some specific strategies for implementing EMAS are identified which are motivated by and adapted to the idiosyncrasies of the university itself. As consequence of the implementation, some milestones have been reached, especially in the area of operational control, as well as at the organizational level. Also notable it is the improvement in environmental awareness, training, communication and information on the EMAS to members of the university, as well as an improvement in the image of the institution in the social, business and political arenas. Finally, certain challenges have been detected and it is assumed that can be addressed using the environmental management system itself.

EMAS appears to be a good environmental management system for university campuses due to its adaptability to the complexity of university organizations and their governance structures.

\section{INTRODUCTION}

Many authors have studied the necessity of sustainable actions in modern universities, the benefits and barriers for their implementation and the methods of assessing, reporting and monitoring these actions (Alshuwaikhat and Abubakar, 2008, Lozano García et al., 2006, Lozano, 2006, Lozano, 2010, Lozano, 2011). With respect to sustainability, the implementation of Environmental Management Systems on campuses is considered not only a way of monitoring and controlling operational aspects but also as a means for creating the necessary setting for sustainable practices in universities (Disterheft et al., 2012, Jones et al., 2012). The European Environmental Management System, Eco-Management and Audit Scheme (EMAS) has been available to companies since 1993, but was originally restricted to companies in industrial sectors. In 2001, EMAS became open to all economic sectors including public and private services. In 2009, EMAS Regulation was newly modified to EMAS III (European Commission, 2009), which became effective on January 11, 2010. The main objective of EMAS III is to provide a management tool for companies and other organizations to evaluate, report, and improve their environmental performance. The aim of EMAS is to recognize and 
reward those organizations that continuously improve their environmental performance and go beyond minimum legal compliance.

According to the study commissioned by the European Union in 2009 (Vernon et al., 2010) about the cost and benefits of EMAS-registered organizations, the reasons for seeking this registration can be very different. Some firms claim that is essential today to enhance transparency with stakeholders and to follow clients' requirements. Furthermore, firms have reported several benefits of EMS implementation, which are (in order of preference) energy and resource savings, improved stakeholder relationships and reduction of negative incidents. In this EU study, there is a consensus among member states that the most important benefits are the increase of efficiency and reduction of costs. However, companies not yet EMS verified do not perceive that these benefits are sufficiently clear.

In recent years, there have been a large number of institutions and companies in Europe that have obtained EMS verification according to EMAS web reports (http://ec.europa.eu/environment/emas/register/reports/reports.do). At the time of writing, 193 educational organizations (under NACE code 85) are verified in EMAS; only 16 of them are European higher education institutions. A list of institutions compiled from the internet and updated from Disterheft et al., (2012) is available in Table 1.

Some strong barriers have been identified in the implementation process that may explain the shortage of EMAS implementation in Universities. Some of these barriers are related to personnel shortage and financial restrictions; other barriers are related to institutional organization of public universities, where direct taxation in implementing EMS has proven to be ineffective. Lozano (2006) also discussed the other difficulties related to institutional change and radical innovation.

Some authors (Clarke and Kouri, 2009) doubt the functionality of EMAS in universities as it was not specifically designed for higher education institutions and these authors therefore see other tools, like the AISHE tool (Roorda and Onderwijs, 2001), the Osnabruck Environmental Model for Universities (Viebahn, 2002) or the Sustainable University Model (Velazquez et al., 2006) as more appropriate. An interesting paper about implementation status of EMS in U.S. Colleges and Universities is presented by Savely et al. (2007); this study concludes that $30 \%$ of colleges and universities have implemented some kind of EMS elements, many of them related to EMAS requirements. 
Another major factor to consider is the difficulty in aligning environmental issues with educational and research goals, a challenge very specific of university. The ambiguity of benefits of implementing EMS in a university is also very closely connected with the organization chart of the public universities and the strong differences with respect to private companies. Although policy directives from the top level must be assumed by all, several academic decisions are only in the hands of faculty, departments and research institutes. A priori, the low separate decisionmaking structures complicate the EMS implementation (Clarke and Kouri, 2009). Nevertheless, in a recent study, Disterheft et al. (2012) examined the implementation of EMS in European Higher Education Institutions. The study concludes that EMS implementation aids in reducing environmental impact of operations and in developing competencies which lead to more sustainable practices in research and teaching. The study claims that the combination of a topdown process with participation can improve not only operational aspects but also create the necessary setting for sustainable practices at universities.

When the university organization chart is compared with private companies, it can be seen that senior management and staff roles are similar to those in industries. However, the students and faculty roles are not comparable to any in the private sector: these stakeholders take part in the election of representatives of governance and parts of these organizations are set by quotas.

Despite all the pros and cons, Universitat Politècnica de València (UPV) has recently verified all organization in EMAS. UPV is a medium size university founded in 1975 (although some of the facilities were built in the $19^{\text {th }}$ century) that now has a student body of more than 30.000 students, (see statistics in Table 2). Implementing an EMS was a challenge with such a large student population and many lessons were learned from this experience.

This paper describes, according with the experience of implementing EMAS at UPV, differences between implementing EMAS at universities and implementation at other organizations, as well as the limitations of EMAS for university campuses, the specific barriers detected in its implementation, and benefits of registration. This study should be useful for universities interested in implementing an EMS and, specifically, according to the EMAS standard. 


\section{METHODOLOGY}

A literature review was conducted of publications, conference proceedings, university reports, books, website documents, and education for sustainability profiles. The ultimate goal of the literature review was the identification of the diverging strategies and practices undertaken by key players in order to be able to compare the UPV experience in EMS implementation with other university and industrial sector experiences.

Most of the data presented in this paper is based on existing documentation at UPV as a result of the EMAS implementation process. The data was collected from the archives of UPV: environmental audits, environmental policy, environmental planning and environmental statements.

Archival research was complemented with interviews, google questionnaire and surveys during 2012, which were conducted with different stakeholders: senior management, environmental officers, environmental committee and environmental contacts.

The questionnaire gathered data about the perception of stakeholders of implementing process, its benefits, drivers and internal barriers. In this study, only the part of benefits, from a qualitative point of view is published as table 6. Other results regarding to drivers and internal barriers will be published in a separated study.

\section{RESULTS}

\section{Background and Implementation Process}

At the beginning of 1990's UPV began implementation of compliance and pollution prevention processes as the first seed planted for the eventual full implementation of an EMS. The actions started with the setup of a small group of staff named "The Green Office" devoted to the control and management of solid and toxic wastes on campuses: it was the first environmental office in a Spanish university.

During this period, UPV studied the possibility of implementing EMAS as a pilot program for the verification of this system in European universities. The strategy was to certify all facilities in ISO 14001 which was considered a valid model in the 1993 version of the EMAS regulation (European Commission, 1993). In 1999, the 
first Environmental Policy Statement (EPS) for all of UPV was approved, and in 2002, three facilities were verified in accordance with ISO 14001.

These actions were paralleled by the leadership of UPV in a European Project about studying a methodology for implementing EMAS at university campuses starting in 1996 (Peris-Mora, 2002). The study revealed that it was possible to improve quality management of universities not only by EMS implementation but also with the verification of the EMS according to EMAS.

During a universal election of the chancellor in 2005, the electoral program of different opponents included the implementation of EMS in the future vision for UPV. The goal of certifying each unit separately was abandoned in 2006, as a result of detecting duplicities that seriously impeded the implementation process of an EMS throughout the entire university. As a result, and following the advice of the Regional Department of Infrastructures, Land and Environment (http://www.cma.gva.es), which is the competent authority in EMAS verification in Valencia Region, this strategy was replaced by another one based on implementing EMAS incrementally throughout the whole university.

The process was carefully planned in 15 phases to meet the requirements of EMAS (Figure 1). For this task, in 2006 the "Green Office" was renamed as the Environmental Office and reinforced with a new full time technician and administrative staff. This office was initially in charge of implementing the EMS, including coordination and control of operations with environmental impact and the internal auditing of EMAS.

For a more comprehensive implementation, and taking into consideration the high complexity of the organization, a network consisting of environmental contacts for each unit was created (Table 3). The duty of this network was to disseminate information to their community about environmental policies, collaborate in operational control and give feedback to the EO.

Another task of the EO was the performance of an Environmental Review. As a result of this review, UPV created a new version of its EPS. The environmental management structure was created and responsibilities were carried out by the Environmental Committee. This committee was composed of members of the faculty, administrative and technical staff, students and top level management. Many of the faculty members were experts in environmental management and environmental technology. 
The step described above was followed by the identification and analysis of environmental aspects of the university and their significance (see Table 4). This was the basis for setting an initial proposal for environmental objectives, with the following phases executed in 2007 and 2008. During this period, the EO reported regularly to the EC regarding the progress of implementation.

In 2009, EMAS was verified and in early 2010 the system was validated. After verification, the organization was nominated in 2009 and 2010 for the EMAS European awards. From 2010 until now, UPV is still the largest University with

EMAS verification (information available at http://ec.europa.eu/environment/emas/register/reports/reports.do).

\section{An Overview of EMAS implementation at UPV}

For implementing EMAS at UPV three new organizational structures were created: the Environmental Office (EO), the Environmental Committee (EC), and the Network of Environmental Unit Contacts (Figure 2)

The EC sets the priorities of the EMS and guides its implementation. It remains under the Board of Governors (BoG) and champions the EMS. The president of EC is the chancellor, and the secretary is the senior technician of the EO. The other members of the staff are student leaders, members of university trade union, faculty, administration and senior management, and other experts in EMS, biology, ecology and engineering. This diverse team is able to troubleshoot problems arising from different management styles and operational structures. Some of the members are working within their job descriptions and others are taking on extra work or are volunteers. One of the most important roles of the EO is to help define corrective actions as a result of assessment reports and to aid in policy review. At present, several units (faculty and departments) involved with the EO have created their own committees to advise unit staff and the University EC.

This office is in charge of implementing and maintaining the EMS. This office develops the network of environmental contacts in all units that collaborate in the implementation of EMS in departments, faculties, and research institutes. The EO also executes the actions approved by the EC and is dependent, from the hierarchical point of view, on the Vice Chancellor for Facilities.

The environmental policy statement includes the institution's commitment to reduce the environmental impact of its operations, including the areas of teaching and 
research. This has led and continues to lead one of the most important tasks of EMAS at UPV, prioritizing and determining the significance of the elements that influence the environment.

UPV has many specific environmental interactions, which have either benefits or risks through their operations, finances, community service, education and research (see Table 4). All environmental interactions are identified, monitored, assessed and recorded systematically.

UPV has also implemented a communication and transparency policy to keep employees, students and the social environment informed about the environmental performance of the university and involved in its management.

The documents of the system and their importance are usual for this kind of EMS. The continuous improvement policy makes it necessary to adopt an annual Environmental Plan (EP) to reduce the environmental impact of the interactions. This plan is proposed with a budget by the EC and approved by the BoG; it contains objectives and goals specifically designed to mitigate the environmental aspects with greatest significance.

Written procedures, documents and records are uploaded onto a server and disseminated to university members (including students) through the intranet according to their specific profiles. A summary of the documentation of the EMS is given in Table 5 .

Every year, an updated Environmental Statement Report (ESR) is published according to EMAS requirements. This document is published at the WEB page of the University and disseminated according to the university's policy of transparency in environmental communication of the University. The 2012 version of this document is available at http://riunet.upv.es/bitstream/handle/10251/29137/UPV.AMA-DA.2012-

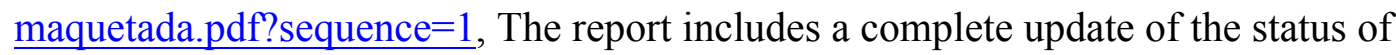
the university with regard to environmental performance, the objectives and the goals achieved and new challenges that are being faced. This document is verified and approved by a competent authority of the European Union.

The environmental vision and mission of UPV was included in the Strategic Plan 2007-2014 (available at http://www.upv.es/noticias-upv/documentos/2714-es.pdf) and described in Goal III: Social Commitment and Values. In this document, the 
vision of UPV stated that it is an 'efficient institution, with a strong social and environmental commitment'.

\section{Benefits}

Table 6 shows benefits of implementing EMAS. These are typical benefits of implementing an EMS (improved operational control; an organization structured that fits the EMS challenges; higher levels of formation and information; etc) (Delakowitz and Hoffmann, 2000).

A summary of environmental performance of the university is available in the $\begin{array}{llll}\text { Environmental Statement } & \text { of }\end{array}$ http://riunet.upv.es/bitstream/handle/10251/29137/UPV.AMA-DA.2012$\underline{\text { maquetada.pdf? sequence }=1}$

\section{New Challenges}

Most of the challenges for improving the EMS at a university campus are the specific to a management system based on continuous improvement that is under the control provided by internal and external audit (Table 6). It is interesting to point out some of the challenges that are closed related to the university's idiosyncrasies (research and educational greening) and the reduction of the environmental impact of key interactions.

For educational purposes, the EMAS at UPV provides an indicator that measures the performance of the core competencies in environmental matters developed in all subjects taught. In the case of research greening, there is another indicator that measures the impact reduction of the research activities in the improvement of the environment and society (see Table 4). As of yet, there are no objectives and actions plans for mainstreaming environmental issues in teaching and research yet. Nevertheless, the use of these indicators is considered a first step prior to the definition and execution of an action plan for mainstreaming environmental issues in curricula and research activities.

The role of UPV in reducing the environmental impact caused by consumption, as well as how to use green procurement to stimulate innovation in environmental technologies, products and services, in accordance with Green Procurement UE Policy is an outstanding issue (European Commission, 2008). Green procurement is only provided at UPV in two procedures for the purchase of recycled paper and toners. Decentralized procurement makes it difficult to implement other measures. 
The lack of information about environmentally sustainable products and services makes the implementation of correction measures especially difficult for this problem.

In accordance with EMAS, direct and indirect environmental aspects at UPV are assessed by considering environmental impacts produced in situ. Thus, the actions of reducing environmental impact and resulting assessments, do not consider the entire life cycle impact. The main difficulty in implementing a life cycle assessment is related to the lack of quality information about life cycle costing of products and services. This is a common problem for all kinds of organizations whose interactions are similar to those at UPV.

Another challenge that requires special attention is the necessity of the reduction of energy consumption, which not only reduces direct and indirect emissions of greenhouse gases and other pollutants, but also may result in a financial cost saving if the energy savings offset any additional costs of implementing an energy efficient technology. Improved energy efficiency in buildings, university processes and transportation is one of the most important goals planned in the EMS.

\section{DISCUSSION}

This section discusses how UPV has dealt with the implementation of the EMAS and overcome some of the barriers identified as being typical of the public university. From the analysis of the actions carried out by UPV, it is possible to identify many of the recommendations proposed by Lozano (2006) for implementing innovative actions in universities and overcoming typical individual barriers (Table 7). The strategies used for this have been largely motivated by the idiosyncrasies of the university itself and adapted to it. As a result, some milestones have been reached which can be considered measurable benefits of implementation. Finally, certain challenges have been detected and it is assumed that can be addressed using the environmental management system itself.

The implementation of EMAS at a university is a unique experience-a special case of EMAS implementation in an education and research center setting-due to the differences of a university with other organizations as industries. Although due to this fact some studies request an specific EMS for universities (Clarke and Kouri, 2009), the experience at UPV shows that EMAS is also adequate for an university 
campus. This fact is only possible if barriers in the implementation are identified and specific strategies are adopted.

UPV, as medium size university, is composed of a great number of different units that must be coordinated (Table 3). These units, in many aspects and from the functional standpoint, act independently and interact with each other in a highly complex fashion. This fact complicates the control, coordination and necessary feedback process between unit operations and the EO. It was necessary to create a new functional structure with new responsibilities and integrate them in the general structure of UPV.

According to Peris-Mora (2002) a successful EMS brought together the skills and expertise of all four stakeholder groups (teachers, researchers, administrative personnel and students) and bridged their varied decision-making and communication structures, ranging from horizontal, autonomous, and democratic to vertical and hierarchical. This does not resemble the structure of companies for which the EMAS was designed. These problems were bypassed by giving authority to the EO to coordinate a network of environmental contacts, one for each unit. This network has made it possible to disseminate information, train and give operational instructions to every corner of the organization. At the same time, the EO has received important feedback regarding the implementation and maintenance process to feed the system and achieve the goal of continuous improvement. This fact has made possible a high level of involvement among different stake holders in the EMS, breaking one of the most important barriers identified by Lozano (2006).

Stakeholders develop, plan, implement, check and review the university EPS. For this reason, the roles and responsibilities of the different members of university organization have also been reviewed and adapted to the new structure of the network of environmental contacts under the coordination of the EO.

In the case of UPV, the decision of implementing EMAS was adopted by the chancellor during the process of a universal election in 2005, motivated by the previous experience in implementing EMS at UPV. The decision of the implementation of EMAS was ratified by electors in a democratic and direct way which made the process more participatory, most common approach in European universities certified in EMAS (Disterheft et al., 2012). This is a substantial difference when compared with private companies, where these decisions are not 
necessarily endorsed by the collective, which will be the ones to make them work and will benefit from them later.

The EC composition is also quite different in universities compared to other organizations (Delakowitz, and Hoffmann, 2000). In industrial companies the EC is made up of members of the operational units, quality department staff and the chief executive officer. In UPV, this committee represents all stakeholders (staff, students, faculty and senior management) which ensure democratic participation in decision-making. Many faculty members are part of the committee because of their expertise in environmental management, ecology, biology and environmental engineering, making the EC a group with high level knowledge in environmental issues. This variety of expertise internal to the organization at the disposal of the same for the implementation and maintenance of the system is somewhat unusual for a private company. This participatory approach complements the necessary topdown approach mentioned above, a good strategy of implementing and EMS according with the results of (Disterheft et al., 2012).

Furthermore, there is a great quantity of environmental aspects to monitor (Figure 4). Almost all potential environmental aspects are present at UPV, something unusual in a private company where the environmental aspects are very closely related to some specific operations (Delakowitz, and Hoffmann, 2000). Once more, the network of environmental contacts is the keystone which controls the environmental aspects and feedback to the system of the information received under the coordination and supervision of the EO.

Control of environmental legislation applicable to UPV is, likewise, more complex than in a private company, because of the variety and huge number of environmental issues. This requires maintaining a constant focus on keeping the information updated and available to all units involved in the EMS. With EMAS, UPV now has a verified method that allows for the monitoring and control of environmental interactions and legal requirements.

The strategy of abandoning the original plan of certifying each unit separately came as a result of detecting duplicities that hindered the implementation process throughout the entire university. These duplicities were the result of the high level of interdependence among the various units which caused the duplication of procedures and functions, and made it impossible to define procedures and a clear and operational organization chart. UPV was ultimately verified as a unique 
organization wherein some operations are linked specifically to units and require special treatment. This decision reduced the complexity of organization and operational control procedures, and resulted in a better adaptation of EMAS to the UPV structure.

It is assumed that the success of the results and implementation process are achieved when the investment in resources and personnel is sufficient to undertake the project (Vernon et al., 2010). In the case of UPV, corporate and senior management commitment was crucial, especially from the chancellor, who was entirely engaged from the beginning of the process. Considering that the election of the chancellor is held every 4 years and that the BoG is refreshed every new election of representatives of stakeholders, the strong will of top management must be maintained and reinforced by the political changes over the institution's own university. In the case of UPV, the implementation process lasted more than 3 years and it was necessary to have a strong investment in a full time staff of technicians to coordinate and execute all requirements of EMAS. The will and the stability of senior management provided the necessary institutional framework to ensure the continuity in the project.

Analysis of the actions carried out by UPV for overcoming typical individual barriers are listed in Table 6.

\section{CONCLUSIONS}

For the implementation of EMAS at a university campus it is necessary to overcome some specific barriers which are typical of the public university. The strategies used for this have been largely motivated by the unique environment of the university itself and adapted to it. As a result, some milestones have been reached which can be considered measurable benefits of implementation.

Certain challenges, as mainstreaming environmental issues in teaching and research and green procurement, have been detected and it is assumed that can be addressed using the EMS itself.

The benefits achieved are related both to the improvement in operational control, and on the organizational level. Also notable is the improvement of environmental awareness, training, and information on the EMAS to members of the university, 
as well as an improvement of the image of the institution in the social, business and political arenas.

At the same time, along with EMAS implementation, internal and the external environmental communication and transparency strategies are included in the policy of UPV.

In conclusion, EMAS can be considered a good environmental management system for university campuses, due to its adaptability to the complexity of university organization, and a very satisfactory model of governance of these institutions. EMAS constitutes an important tool among university sustainability initiatives.

\section{REFERENCES}

Alshuwaikhat and H.M., Abubakar, I., (2008). "An integrated approach to achieving campus sustainability: assessment of the current campus environmental management practices", J. Clean. Prod. Vol. 16, pp. 1777-1785

Clarke, A. and Kouri, R., (2009). "Choosing an appropriate university or college environmental management system", J. Clean. Prod. Vol. 11, pp. 971-984

Delakowitz, B. and Hoffmann, A., (2000). "The Hochschule Zittau/Görlitz: Germany's first registered environmental management (EMAS) at an institution of higher education", International Journal of Sustainability in Higher Education, Vol. 1, pp. 35-47

Disterheft, A., da Silva Caeiro, S.S.F., Ramos, M.R. and de Miranda Azeiteiro, U.M., (2012). "Environmental Management Systems (EMS) implementation processes and practices in European Higher Education Institutions-top-down versus participatory approaches", J. Clean. Prod. Vol. 31, pp. 80-90.

Environmental Protection Agency, (2001). "Environmental management system initiatives", working paper, Environmental Protection Agency, available at http://www.newmoa.org/prevention/newsletters/11_1/vol11_1.htm, (accessed 16 December 2012). 
European Commission, (2009). "No, R.;1221/2009 of the European Parliament and of the Council of 25 November 2009 on the voluntary participation by organisations in a Community eco-management and audit scheme (EMAS), repealing Regulation (EC) No 761/2001 and Commission Decisions 2001/681/EC and 2006/193", available at

http://eurlex.europa.eu/LexUriServ/LexUriServ.do?uri=OJ:L:2009:342:0001:01:EN:HTM $\underline{L}$ (accessed 16 December 2012).

European Commission, (2008). "Public procurement for a better environment. Communication from the Commission to the European Parliament, The Council, The European Economic and Social Committee and the Committee of the Regions", available at http://eurlex.europa.eu/LexUriServ/LexUriServ.do?uri=COM:2008:0400:FIN:EN:HTML (accessed 16 December 2012).

European Commission, (1993). "Council Regulation (EEC) No 1836/93 of 29 June 1993 allowing voluntary participation by companies in the industrial sector in a Community eco-management and audit scheme. Official Journal L. 10/07, 00010018", available at http://eurlex.europa.eu/LexUriServ/LexUriServ.do?uri=OJ:L:2001:114:0001:0029:EN:PD F (accessed 16 December 2012).

Jones, N., Panoriou, E., Thiveou, K., Roumeliotis, S., Allan, S., Clark, J.R.A. and Evangelinos, K., (2012). "Investigating benefits from the implementation of Environmental Management Systems in a Greek university. Clean Technologies and Environmental Policy", Vol. 4, Issue 4, pp. 669-676.

Lozano García, F.J., Kevany and K., Huisingh, D., (2006). "Sustainability in higher education: what is happening?", J. Clean. Prod. Vol. 9, pp. 757-760

Lozano, R., (2011). "The state of sustainability reporting in universities", International Journal of Sustainability in Higher Education. Vol. 1, pp. 67-78 
Lozano, R., (2010). "Diffusion of sustainable development in universities' curricula: an empirical example from Cardiff University". J. Clean. Prod. Vol. 7, pp. 637-644

Lozano, R., (2006). "Incorporation and institutionalization of SD into universities: breaking through barriers to change", J. Clean. Prod. Vol. 9, pp. 787-796

Peris-Mora, E., (2002). "Environmental Responsibility of Universities. The Environmental Management Systems", Environmental Management Systems for Sustainable Universities Conference 2002, pp. 339-346

Roorda, N. and Onderwijs, S.D.H., (2001). "AISHE: auditing instrument for sustainability in higher education", available at http://www.eauc.org.uk/audit instrument for sustainability in higher educ, (accessed 16 December 2012).

Savely, S.M., Carson, A.I. and Delclos, G.L., (2007). "A survey of the implementation status of environmental management systems in US colleges and universities". Journal of Cleaner Production, Vol. 7, pp. 650-659

Velazquez, L., Munguia, N., Platt, A. and Taddei, J., (2006)." Sustainable university: what can be the matter?", J. Clean. Prod. Vol. 9, pp. 810-819

Vernon, J., Peacock, M., Belin, A., Ganzleben, C. and Candell, M., (2010). "Study on the Costs and Benefits of EMAS to Registered Organizations", available at http://ec.europa.eu/environment/emas/pdf/news/costs and benefits_of_emas.pdf, (accessed 16 December 2012).

Viebahn, P., (2002). "An environmental management model for universities: from environmental guidelines to staff involvement", Journal of Cleaner Production, Vol. 1, pp. 3-12. 
Figure 1. EMAS implementation phases at UPV

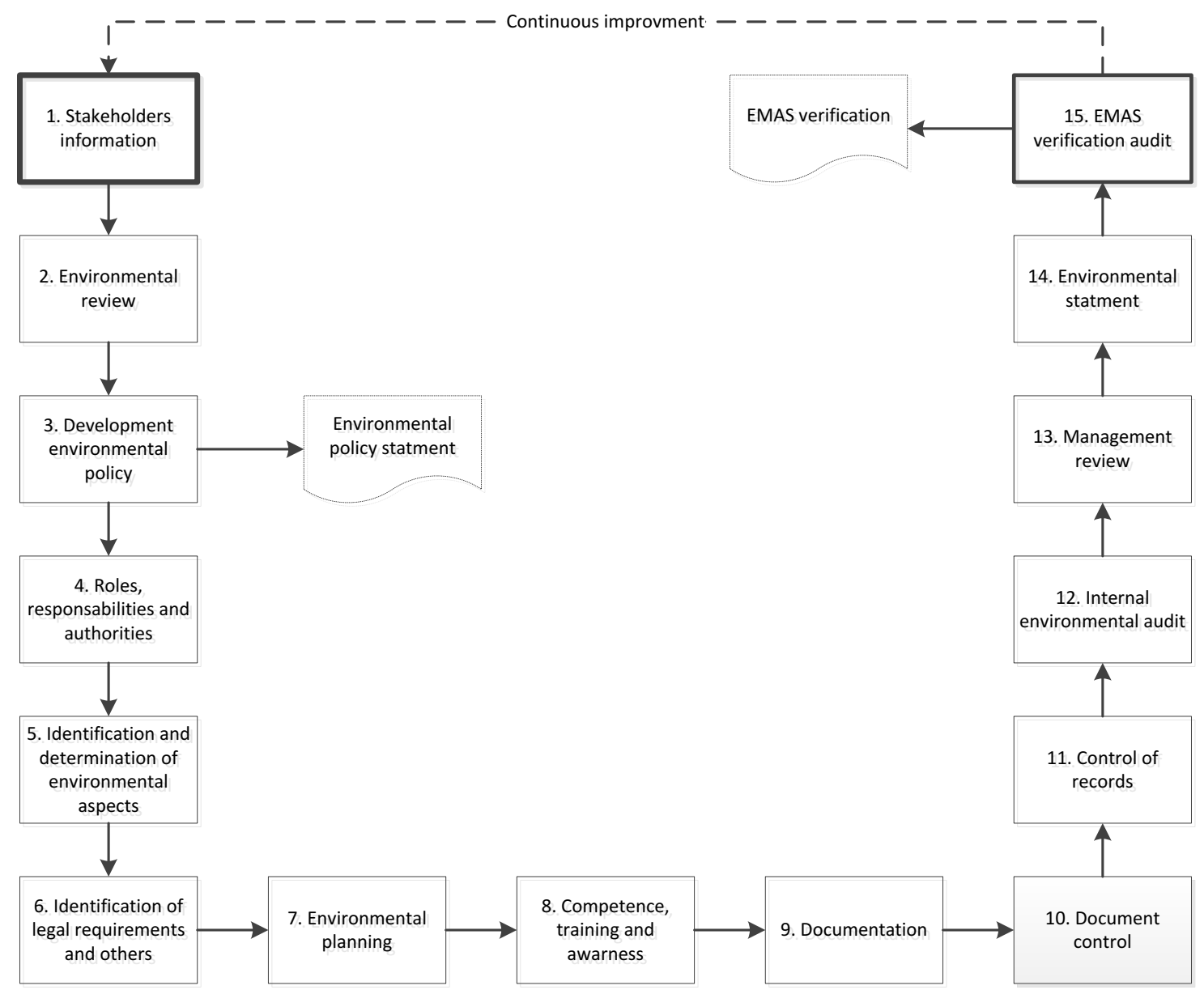


Figure 2: Typical organization chart of a public university in Spain. Slashes show elected representatives; dots show new functional organization structures that arose as consequence of implementation of EMAS at UPV. For further information about public Spanish university organization see: http://www.crue.org/legislacion/lou.html)

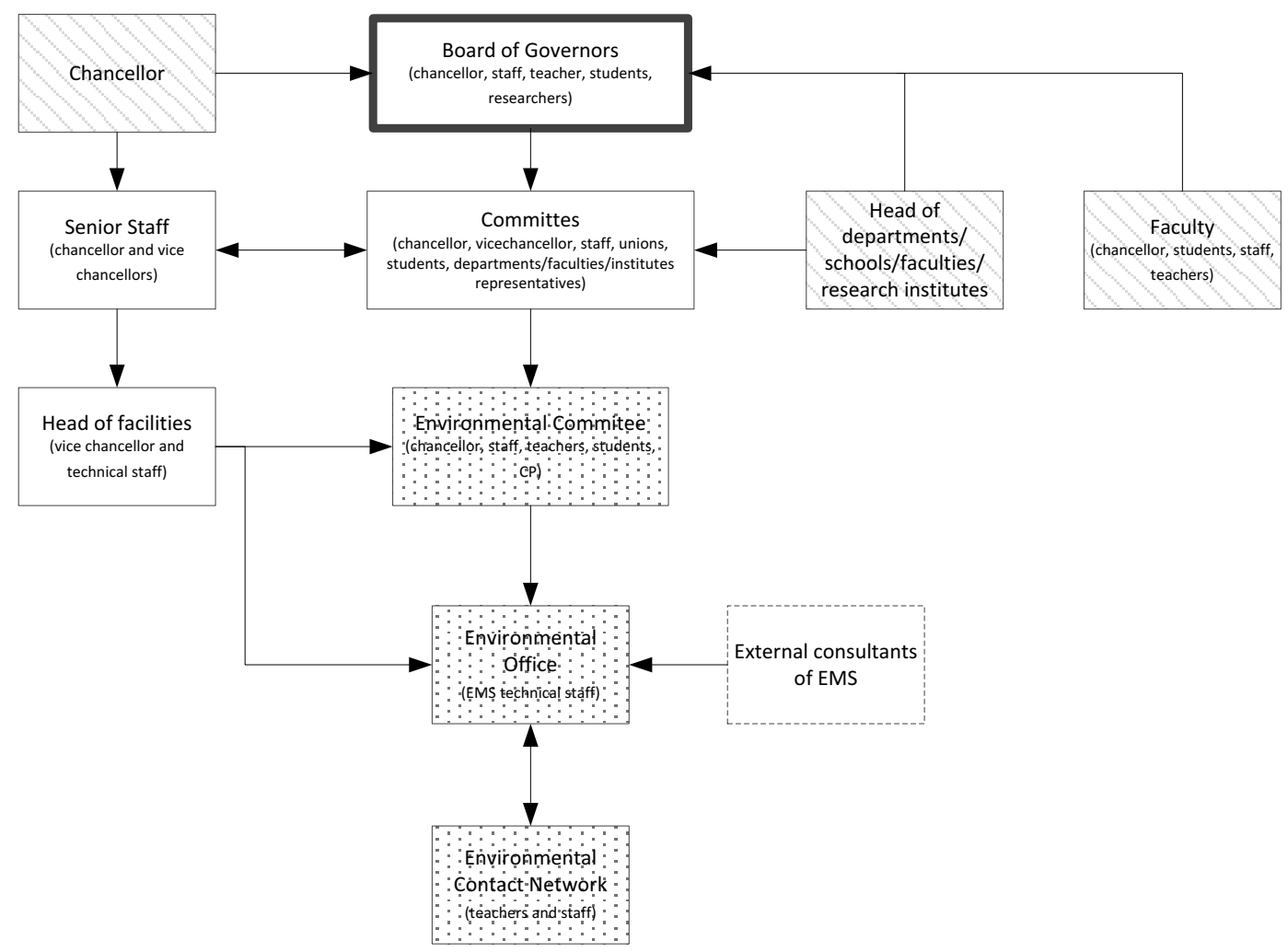


Table 1: List of universities and higher education institutions that have reported EMAS verification in all or a part of the organization in last 12 years. Except "Escola Superior Agrária de Coimbra" and "University of Applied Science Hochschule Zittau/Gorlitz", all of them are listed in EMAS validated list (according to NACE* code 85.4)

\begin{tabular}{|c|c|c|c|c|}
\hline University & $\begin{array}{l}\text { Year of } \\
\text { report }\end{array}$ & $\begin{array}{l}\text { Reference or web page } \\
\text { available }\end{array}$ & Country & Comments \\
\hline $\begin{array}{l}\text { Escuela de Organización } \\
\text { Industrial - Fundación EOI }\end{array}$ & 2005 & http://www.eoi.es & Spain & \\
\hline $\begin{array}{l}\text { Escola Superior Agrária de } \\
\text { Coimbra }\end{array}$ & 2006 & http://portal.esac.pt/portal & Portugal & $\begin{array}{l}\text { Validation } \\
\text { suspended }\end{array}$ \\
\hline $\begin{array}{l}\text { Fachhochschule Köln } \\
\text { Geisteswissenschaftliches } \\
\text { Zentrum }\end{array}$ & 2008 & http://www.fh-koeln.de & Germany & \\
\hline $\begin{array}{l}\text { Fachhochschule Wiener } \\
\text { Neustadt für Wirtschaft und } \\
\text { Technik GmbH, Campus } \\
\text { Wieselburg }\end{array}$ & 2009 & http://www.fhwn.ac.at & Austria & \\
\hline Faserinstitut Bremen e. V. & 2004 & http://www.faserinstitut.de & Germany & \\
\hline Fachhochschule Eberswalde & 2010 & $\begin{array}{l}\text { http://www.hnee.de/HNE- } \\
\text { Eberswalde-E1016.htm }\end{array}$ & Germany & \\
\hline Göteborgs Universitet & 2004 & http://www.gu.se/english & Sweden & \\
\hline $\begin{array}{l}\text { Hochschule für angewandte } \\
\text { Wissenschaften Fachhochschule } \\
\text { Landshut }\end{array}$ & 2002 & $\begin{array}{l}\text { http://www.upv.es/noticias } \\
\text {-upv/documentos/2714- } \\
\text { es.pdf }\end{array}$ & Germany & \\
\hline $\begin{array}{l}\text { Leuphana Universität Lüneburg } \\
\text { Campus Lüneburg e.V. Campus } \\
\text { Management GmbH }\end{array}$ & 2000 & $\begin{array}{l}\text { http://www.leuphana.de/en } \\
\text { /home.html }\end{array}$ & Germany & \\
\hline $\begin{array}{l}\text { Liceo Scientifico Statale } \\
\text { "Alvise Cornaro" }\end{array}$ & 2005 & $\begin{array}{l}\text { http://www.liceocornaro.c } \\
\text { om/Home_Page.html }\end{array}$ & Italy & \\
\hline $\begin{array}{l}\text { Stiftung St. Franziskus } \\
\text { Heiligenbronn }\end{array}$ & 2009 & $\begin{array}{l}\text { http://www.stiftung-st- } \\
\text { franziskus.de/ }\end{array}$ & Germany & \\
\hline Technische Universität Dresden & 2003 & $\begin{array}{l}\text { http://www.boku.ac.at/ho } \\
\text { me.html?\&L=1 }\end{array}$ & Germany & \\
\hline $\begin{array}{l}\text { Universität für Bodenkultur } \\
\text { Wien }\end{array}$ & 2006 & $\begin{array}{l}\text { http://www.upv.es/noticias } \\
\text {-upv/documentos/2714- } \\
\text { es.pdf }\end{array}$ & Austria & \\
\hline $\begin{array}{l}\text { Universitat Politècnica de } \\
\text { València }\end{array}$ & 2010 & www.upv.es & Spain & \\
\hline $\begin{array}{l}\text { University of Applied Science } \\
\text { Hochschule Zittau/Gorlitz }\end{array}$ & 1999 & $\begin{array}{l}\text { (Delakowitz, and } \\
\text { Hoffmann, 2000). }\end{array}$ & Germany & $\begin{array}{c}\text { Not additional } \\
\text { information }\end{array}$ \\
\hline $\begin{array}{l}\text { University of Macedonia, } \\
\text { Economic and Social Sciences }\end{array}$ & 2005 & http://www.uom.gr & $\begin{array}{l}\text { Republic of } \\
\text { Macedonia }\end{array}$ & \\
\hline
\end{tabular}


Table 2: UPV in figures (2012)

\begin{tabular}{l|lllll} 
Campus & $\begin{array}{l}\text { Students } \\
\text { (full-time) }\end{array}$ & Teacher/Others & $\begin{array}{l}\text { Total Floor } \\
\text { Area }\end{array}$ & Landscaping area & WEB link \\
\hline Valencia & 31487 & $2401 / 4712$ & $624319 \mathrm{~m}^{2}$ & $117,055 \mathrm{~m}^{2}$ & www.upv.es \\
Gandía & 1851 & $167 / 85$ & $32,416 \mathrm{~m}^{2}$ & $7,020 \mathrm{~m}^{2}$ & www.gandia.upv.es \\
Alcoy & 2271 & $186 / 84$ & $23,633 \mathrm{~m}^{2}$ & - & www.epsa.upv.es \\
\cline { 1 - 4 } UPV & $\mathbf{3 8 1 9 6}$ & $\mathbf{2 7 5 4 / 4 8 8 1}$ & $\mathbf{5 9 9 , 4 2 4} \mathbf{~ m}^{2}$ & $\mathbf{1 1 3 , 3 7 8 \mathbf { ~ m } ^ { 2 }}$ &
\end{tabular}


Table 3: UPV units considered in EMS.

\begin{tabular}{|l|l|c|c|c|c|}
\hline \multicolumn{2}{|c|}{ Activity } & $\begin{array}{c}\text { Alcoy } \\
\text { Campus } \\
(*)\end{array}$ & $\begin{array}{c}\text { Gandía } \\
\text { Campus } \\
(*)\end{array}$ & $\begin{array}{c}\text { Vera } \\
\text { Campus } \\
(* *)\end{array}$ & UPV \\
\hline \multirow{3}{*}{ Teaching } & Faculties & 1 & 1 & 12 & $\mathbf{1 4}$ \\
\cline { 2 - 7 } & Departments & 1 & 0 & 43 & $\mathbf{4 4}$ \\
\cline { 2 - 7 } & Department in smaller campuses & 22 & 27 & - & $\mathbf{3 5}$ \\
\hline Research Facilities & 0 & 0 & 35 & $\mathbf{9 1}$ \\
\hline University services & \multicolumn{2}{|c|}{ Common } & 91 & $\mathbf{2 7}$ \\
\hline Third party facilities & 2 & 2 & 23 & $\mathbf{2 1 1}$ \\
\hline Total UPV
\end{tabular}

* Alcoy and Gandía are cities of Valencia region where UPV is present;

** Vera is a suburb of Valencia City where the main campus of UPV is based. 
Table 4: List of environmental interactions assessed in normal operating conditions at UPV. The quantitative measure of the interaction was calculated as result of multiplying 4 parameters: (1) scale (flux or concentration), (2) how closer is to legal limits, (3) dangerousness and (4) extent (quantity of people affected)

\begin{tabular}{|c|c|c|}
\hline Category & Environmental interaction & Potential Environmental Impact \\
\hline Teaching & Greening curricula & Lack of environmental training \\
\hline Research & Greening research & Unsustainability practice \\
\hline \multirow{3}{*}{$\begin{array}{l}\text { Material resource } \\
\text { consumption }\end{array}$} & Toners & \multirow{3}{*}{$\begin{array}{l}\text { Material resource depletion and } \\
\text { pollution }\end{array}$} \\
\hline & Paper & \\
\hline & Chemical Products & \\
\hline \multirow{4}{*}{$\begin{array}{l}\text { Natural resource } \\
\text { consumption }\end{array}$} & Tap water & \multirow[t]{2}{*}{ Natural resource depletion } \\
\hline & Well water & \\
\hline & Energy & \multirow{2}{*}{$\begin{array}{l}\text { Natural resource depletion } \\
\text { Climate change }\end{array}$} \\
\hline & Fuels & \\
\hline Third party activities & Environmental behavior of third party firms & All \\
\hline \multirow[t]{29}{*}{ Wastes } & Paper and cardboard & \multirow[t]{29}{*}{ Pollution of soils and water resources } \\
\hline & Plastic Packaging & \\
\hline & Glass Packaging & \\
\hline & Other wastes & \\
\hline & Toners & \\
\hline & Compaq discs & \\
\hline & Biohazardous and medical & \\
\hline & Cytotoxic & \\
\hline & Chemical (solid) & \\
\hline & Inorganic acids & \\
\hline & Organic acids, salts and peroxides & \\
\hline & Cyanide substances & \\
\hline & Unknown products with high toxicity & \\
\hline & Halogen solvents & \\
\hline & Non halogen solvents & \\
\hline & Substances that increase COD & \\
\hline & Packaging of dangerous products & \\
\hline & Phenols and phenolic compounds & \\
\hline & Photographic liquids & \\
\hline & $\begin{array}{l}\text { Heavy metals and compounds of } \mathrm{Hg} \text { and } \\
\mathrm{Cr}(\mathrm{VI})\end{array}$ & \\
\hline & Organohalogen compounds & \\
\hline & Alkalis and inorganic salts & \\
\hline & Electric and electronic & \\
\hline & Cells and batteries & \\
\hline & Mineral and other oils & \\
\hline & Vegetable oils and fats & \\
\hline & Manure & \\
\hline & Sewage sludge & \\
\hline & Carcasses & \\
\hline Effluents & Wastewaters & Pollution of water resources \\
\hline Noise & Noise & Noise pollution \\
\hline Transport & Mobility & All \\
\hline
\end{tabular}


Table 5: Summary of the EMAS documentation at UPV

\begin{tabular}{|c|c|c|}
\hline EMAS requirements* & UPV Documents & Observation \\
\hline $\begin{array}{l}\text { The environmental policy, } \\
\text { objectives and targets }\end{array}$ & $\begin{array}{l}\text { Environmental } \\
\text { Policy }\end{array}$ & Current version in force since 2007 \\
\hline $\begin{array}{l}\text { Description of the scope of the } \\
\text { environmental management } \\
\text { system }\end{array}$ & Manual of EMS & Current version is in force since October 2011 \\
\hline $\begin{array}{l}\text { Description of the main elements } \\
\text { of the environmental management } \\
\text { system and their interaction, and } \\
\text { reference to related documents. }\end{array}$ & Manual of EMS & Current version is in force since October 2011 \\
\hline $\begin{array}{l}\text { Documents, including records, } \\
\text { required by EMAS. }\end{array}$ & Structural procedures & $\begin{array}{l}17 \text { procedures comprise this section of } \\
\text { documents required specifically by EMAS. }\end{array}$ \\
\hline $\begin{array}{l}\text { Documents, including records, } \\
\text { determined by the organisation to } \\
\text { be necessary to ensure the } \\
\text { effective planning, operation and } \\
\text { control of processes that relate to } \\
\text { its significant environmental } \\
\text { aspects }\end{array}$ & $\begin{array}{l}\text { Operational control } \\
\text { procedures } \\
\text { Technical } \\
\text { Instructions }\end{array}$ & $\begin{array}{l}25 \text { Operational Procedures that covers all } \\
\text { environmental aspects of the university. } \\
\text { Currently, there are } 4 \text { "Technical Instructions" } \\
\text { available that support technical instructions for } \\
\text { several procedures as energy data conversion } \\
\text { and materials calculation, between others. }\end{array}$ \\
\hline
\end{tabular}

* According to Annex II of "No, R.;1221/2009 of the European Parliament and of the Council of 25 November 2009 on the voluntary participation by organisations in a Community ecomanagement and audit scheme (EMAS), repealing Regulation (EC) No 761/2001 and Commission Decisions 2001/681/EC and 2006/193" 
Table 6: Summary of Benefits and challenges of the EMS at UPV according to stakeholder's opinion collected with questionnaires.

\begin{tabular}{|c|c|c|}
\hline & Operational control & $\begin{array}{l}\text { Control and assessment of all environmental interactions } \\
\text { Increase in quantity of waste that are managed } \\
\text { Reduction in energy consumption in several units } \\
\text { Control and assessment of environmental law accomplishment } \\
\text { External audit }\end{array}$ \\
\hline Benefits & $\begin{array}{l}\text { Organizational } \\
\text { Structure }\end{array}$ & $\begin{array}{l}\text { A consolidated group of specialist staff in EMS } \\
\text { Organizationally environmental structure fully integrated in } \\
\text { university management and in the decisions making structure of } \\
\text { university }\end{array}$ \\
\hline & Formation & $\begin{array}{l}\text { Improvement of the training of member and senior staff involved } \\
\text { directly in EMS }\end{array}$ \\
\hline & $\begin{array}{l}\text { Communication and } \\
\text { Information }\end{array}$ & $\begin{array}{l}\text { Higher level of sensitizing in the university members, especially } \\
\text { for the case of teachers and staff } \\
\text { A better corporate image of the university }\end{array}$ \\
\hline \multirow{4}{*}{ Challenges } & Operational control & $\begin{array}{l}\text { Action plan for greening the curricula and the research } \\
\text { Mainstreaming green procurement } \\
\text { Extend the use of Life Cycle Thinking in environmental } \\
\text { assessment of all interactions } \\
\text { Reduce energy and material consumption } \\
\text { Increase the efficiency in wastewater, wastes and emissions } \\
\text { management }\end{array}$ \\
\hline & $\begin{array}{l}\text { Organizational } \\
\text { Structure }\end{array}$ & $\begin{array}{l}\text { Open new ways to achieve greater participation of members of the } \\
\text { university in EMS }\end{array}$ \\
\hline & Formation & $\begin{array}{l}\text { Increase the training in EMS of university members and senior } \\
\text { staff } \\
\text { Increase the environmental sensitizing of stakeholder, specially of } \\
\text { students }\end{array}$ \\
\hline & $\begin{array}{l}\text { Communication and } \\
\text { Information }\end{array}$ & $\begin{array}{l}\text { Increase the level of internal and external information and it } \\
\text { effectiveness. } \\
\text { Increase the level of sensitizing in the students }\end{array}$ \\
\hline
\end{tabular}


Table 7: Recommendations of Lozano (2006) for implementing Sustainable Development (SD) at universities and UPV actions according to implementation of EMAS

\begin{tabular}{|c|c|}
\hline Recommendations of Lozano (2006) & UPV actions \\
\hline $\begin{array}{l}\text { The universities' leaders must recognize that working towards SD is } \\
\text { a necessity in the current world, where economic processes are } \\
\text { rapidly degrading the natural and human resources upon which } \\
\text { societies are totally and mutually interdependent }\end{array}$ & $\begin{array}{l}\text { During a universal election of the } \\
\text { chancellor in 2005, the electoral } \\
\text { program of different opponents } \\
\text { included the implementation of EMS } \\
\text { in the future vision for UPV. }\end{array}$ \\
\hline $\begin{array}{l}\text { The individual(s) that are willing to become SD champion(s) must } \\
\text { be identified, engaged and supported with official authority and } \\
\text { financial means. This champion or champions must receive a proper } \\
\text { SD education and be highly motivated and skilled in educating and } \\
\text { motivating others to also become engaged in the SD journey. }\end{array}$ & $\begin{array}{l}\text { Creation of EO, EC and the network } \\
\text { of environmental contacts (see figure } \\
\text { 2) }\end{array}$ \\
\hline $\begin{array}{l}\text { The university policies and strategies must be designed to } \\
\text { holistically integrate SD as the golden thread throughout the } \\
\text { university system. After this, the process of implementation in the } \\
\text { five dimensions must be started with real involvement at all levels. } \\
\text { The following steps may be among the first ones to be started: (a) } \\
\text { implement resource savings, recycling and green procurement via } \\
\text { the campus operations, since this will provide quick and visible } \\
\text { results rapidly; (b) make course and curricular changes after } \\
\text { educating educators on the concepts, tools and approaches in SD; (c) } \\
\text { work with research coordinators and the individual researches to } \\
\text { help them to incorporate SD into their disciplinary, interdisciplinary } \\
\text { and trans-disciplinary research; (d) incorporate SD into all outreach } \\
\text { activities; (e) establish clear goals, objectives, indicators and } \\
\text { methods for easy assessment, reporting, analysis and comparison and } \\
\text { (f) use the reports and related information to accelerate the } \\
\text { incorporation of SD among all university stakeholders. }\end{array}$ & $\begin{array}{l}\text { (a) operational control; } \\
\text { (b) and (c) effort in mainstreaming } \\
\text { environmental issues in teaching and } \\
\text { research; } \\
\text { (d) environmental statement; } \\
\text { (e) environmental plans; } \\
\text { (7) internal formation and sensitizing } \\
\text { actions }\end{array}$ \\
\hline $\begin{array}{l}\text { The university should ensure continuity within a clear and } \\
\text { transparent framework and a long-term plan for institutionalization } \\
\text { of SD. }\end{array}$ & Environmental policy statement. \\
\hline $\begin{array}{l}\text { Establish a high level SD coordinator position which is empowered } \\
\text { and funded to ensure SD continuity. }\end{array}$ & $\begin{array}{l}\text { EC and EO included in organizational } \\
\text { structure (see figure 2) }\end{array}$ \\
\hline $\begin{array}{l}\text { Verify that SD is included in the five dimensions (curricula, } \\
\text { research, campus operations, outreach, and assessment and } \\
\text { reporting). }\end{array}$ & $\begin{array}{l}\text { All dimensions are included in EMS } \\
\text { although curricula and research are } \\
\text { still to be developed fully }\end{array}$ \\
\hline $\begin{array}{l}\text { Perform thorough and regular assessment on where your university } \\
\text { stands on the five dimensions and compare with your plan's goals. } \\
\text { By detecting the individuals, departments and centers that (a) are the } \\
\text { most eager to work with SD, and (b) the most reluctant will help to } \\
\text { detect the innovators and laggards. The first ones can be used as } \\
\text { multipliers by educating the educators, and the last to be able to } \\
\text { detect the highest change level and take the appropriate measures. }\end{array}$ & $\begin{array}{l}\text { Regular audits and environmental } \\
\text { plan revision }\end{array}$ \\
\hline Plan and implement regular reporting of campus SD achievements. & $\begin{array}{l}\text { Environmental statement repots EMS } \\
\text { at university yearly. Online WEB and } \\
\text { intranet communication assure } \\
\text { continuous flux of information with } \\
\text { stakeholders }\end{array}$ \\
\hline
\end{tabular}

